\title{
Soil carbon for food security and climate change mitigation and adaptation
}

\author{
Oladimeji I. Oladele, ${ }^{1}$ Ademola K. Braimoh² \\ ${ }^{1}$ Department of Agricultural Economics and Extension, North-West University, Mafikeng Campus, \\ South Africa; ${ }^{2}$ Agricultural and Rural Development, The World Bank, Washington, DC, USA
}

\section{Introduction}

Agriculture constitutes the backbone of most African economies. It is the largest contributor to gross domestic product (GDP), the biggest source of foreign exchange, accounting for about $40 \%$ of the continent's foreign currency earnings, and the main generator of savings and tax revenues. In addition, about two-thirds of manufacturing value added tax is based on agricultural raw materials. Agriculture remains crucial for pro-poor economic growth in most African countries, as rural areas support $70-80 \%$ of the total population. More than in any other sector, improvements in agricultural performance have the potential to increase rural incomes and purchasing power for large numbers of people to lift them out of poverty (NEPAD, 2002; Wiggins, 2006). Agriculture is important for food security in two ways: it produces the food people eat, and (perhaps even more important) it provides the primary source of livelihood for $36 \%$ of the world's total workforce. In the heavily populated countries of Asia and the Pacific region, this share ranges from $40-50 \%$, and in sub-Saharan Africa, two-thirds of the working population still make their living from agriculture (ILO, 2007). If agricultural production in the low-income developing countries of Asia and Africa is adversely affected by climate change, the livelihoods of large numbers of the rural poor will be put at risk and their vulnerability to food insecurity increased. Climate change, however, is considered as posing the greatest threat to agriculture and food security in the $21^{\text {st }}$ century, particularly in many of the poor, agriculture-based countries of sub-Saharan Africa (SSA) with their low capacity for effective management (Shah et al., 2008; Nellemann et al., 2009). African agriculture is already under stress as a result of an increase in population, industrialization and urbanization, competition over the use of resources, degradation of resources, and insufficient public spending for rural infrastructure and services. The impact of climate change is likely to exacerbate these stresses even further.

Correspondence: Dr. Oladimeji I. Oladele, Department of Agricultural Economics and Extension, North-West University, Mafikeng Campus, South Africa. E-mail: oladele20002001@yahoo.com

Key words: food security, climate change, agriculture, Africa.

Received for publication: 26 September 2011.

Accepted for publication: 5 November 2011.

(C) Copyright O.I. Oladele and A.K. Braimoh, 2011

Licensee PAGEPress, Italy

Italian Journal of Agronomy 2011; 6:e38

doi:10.4081/ija.2011.e38

This work is licensed under a Creative Commons Attribution NonCommercial 3.0 License (CC BY-NC 3.0).
Agriculture is extremely vulnerable to climate change, which is the consequence of the unimpeded growth of greenhouse gas emissions, resulting in raising of the earth's temperature, melting glaciers, increased precipitation, extreme weather events, and shifting seasons. The accelerating pace of climate change, combined with global population and income growth, threatens food security (IPCC, 2007). Higher temperatures eventually reduce yields of desirable crops, while encouraging weed and pest proliferation. Changes in precipitation patterns increase the likelihood of short-term crop failures and long-term production declines. Although there will be gains in some crops in some regions of the world, the overall impact of climate change on agriculture is expected to be negative, threatening global food security. This has implications for populations in the developing world who are already vulnerable and food insecure, and who are likely to be the most seriously affected. In 2005 , nearly half of the economically active population in developing countries (2.5 billion people) relied on agriculture for their livelihood and currently $75 \%$ of the world's poor live in rural areas (World Bank, 2008). The International Food Policy Research Institute (IFPRI, 2009) reported that climate change will result in additional price increases for the most important agricultural food crops such as rice, wheat, maize, and soybeans, and higher feed prices will result in higher meat prices. As a result, climate change will slightly reduce the growth in meat consumption and cause a more substantial fall in cereal consumption. The impacts of climate change on agriculture and human well-being include: a) the biological effects on crops on which livestock feed; b) the resulting impact on outcomes, including prices, production, and consumption; and c) the impact on per capita calorie consumption and child malnutrition. The biophysical effects of climate change on agriculture induce changes in production and prices, which play out through the economic system as farmers and other market participants adjust autonomously, altering crop mix, input use, production, food demand, food consumption, and trade. Climate-change adaptation is increasingly on the agenda of researchers, policymakers, and program developers who are aware that climate change is real and threatens to undermine social and ecological sustainability. In agriculture, adaptation efforts focus on implementing measures that help build rural livelihoods that are more resilient to climate variability and disaster (World Bank, 2008).

The links between climate change and food security have, to date, largely been explored in relation to the impact on crop productivity and hence, food production. According to the FAO (2010), climate change affects all four dimensions of food security; food production and availability, stability of food, access to food supplies, and food utilization. The International Panel on Climate Change (IPCC) defines climate mitigation as any action taken to permanently eliminate or reduce the long-term risk and hazards of climate change to human life, property, an anthropogenic intervention to reduce the sources or enhance the sinks of greenhouse gases, while climate adaptation refers to the ability of a system to adjust to climate change (including climate variability and extremes) to moderate potential damage, to take advantage of opportunities, or to cope with the consequences. Prominent among the mitigation and adaptation strategies is the improvement and increas- 
ing of soil carbon stocks (Ringler et al., 2010).

The world's soil is a major store of carbon; approximately three times the amount in the air and five times as much as in forests. Soil carbon losses caused by agriculture account for a tenth of total $\mathrm{CO}_{2}$ emissions attributable to human activity. However, unlike the carbon released from fossil fuels, the soil carbon store has the potential to be recreated to a substantial degree if appropriate farming practices are adopted. The soil carbon sequestration potential of agriculture depends greatly on the initial carbon levels of the soil and management practices including the intensity of organic inputs (IFOAM, 2009). Practices that increase carbon sequestration have additional benefits, including increased root biomass, soil organic matter, water and nutrient retention capacity and, hence, land productivity. Investments in improved land management leading to increased soil fertility and carbon sequestration can often be justified by their contributions to agronomic productivity, national economic growth, food security and biodiversity conservation (FAO, 2004).

\section{Materials and Methods}

The methodology used in this paper recognizes the concept set out by Vagen et al. (2005) that there are important limits and constraints to current estimates of soil organic carbon (SOC) stocks in SSA, particularly related to lack of, or uncertain estimates of, soil bulk density due to methodological problems. Different authors use different methods (i.e. core method, clod method, etc.) and this contributes to the uncertainty in estimates. Furthermore, results from different studies are reported for different depths $(e . g .0-10,0-20,0-30 \mathrm{~cm})$, which makes the assessment of changes in SOC stocks and the adjustment needed to enable comparisons of different studies more complicated. In this study, 313 estimates from 32 countries were covered in a review of the scientific literature on soil carbon sequestration in Africa. The study was carried out to assess the greenhouse gas mitigation potential of different tree crop farming and agroforestry practices using online scholarly and scientific databases, as well as more general search engines such as Google. The review covered carbon sequestration field measurements and modeled estimates. All studies adopted formal experimental designs, setting up control and treatments. The variations applied in the treatments accounted for the different levels of carbon added to the soil. Most studies reported concentrations of carbon in soil samples (Cc in $\mathrm{g} \mathrm{kg}^{-1}$ ). These were converted to volumes and then areas to calculate stocks ( $\mathrm{Cs}$ in $\mathrm{kg}-1 \mathrm{ha}^{-1}$ ) and sequestration rates ( $\mathrm{kg} \mathrm{ha-1} \mathrm{yr}^{-1}$ ) using bulk density (BD in $\mathrm{g} \mathrm{cm}^{-3}$ ) and sample soil depth (D, in $\mathrm{cm})$ :

$$
\mathrm{C}_{\mathrm{s}}=\mathrm{BD} \times \mathrm{C}_{\mathrm{c}} \times \mathrm{D} \times 10000
$$

In some studies, values were given in terms of percent (\%) of soil organic matter. In these cases, concentrations of $\mathrm{Cc}(\mathrm{g} \mathrm{kg}-1)$ were calculated according to Guo and Gifford (2002) as follows:

$$
\mathrm{C}_{\mathrm{c}}=0.58 \times 0 \mathrm{M} \% \times 10
$$

In some cases, only a single value, either initial or average across treatments, was provided for bulk density. In these cases, that value was assumed to apply to all treatments. No corrections were made for changes in bulk density among treatments (for instance to soil-equivalent mass), but if authors made these adjustments they were used. The effect of a practice was normally estimated by comparing the final level of soil carbon stock in one treatment with that practice and an appropriate control. Thus all soil carbon sequestration rate estimates in this paper are estimates of effect size (the difference with respect to a control) and therefore represent the additional or marginal benefit of practice change. The review covered carbon sequestration field measurements and modeled estimates that were standardized through conversion to the same unit of carbon sequestration in $\mathrm{Kg} \mathrm{C} \mathrm{ha}^{-1} \mathrm{yr}^{-1}$. The analyses carried out were kept simple given constraints in the dataset. Effect sizes and importance of contextual variables were summarized by means and $95 \%$ confidence intervals for the mean. Associations were context variables that were assessed by grouping observations into classes so that non-linear patterns could be clearly identified.

\section{Results}

The amount of carbon sequestered by each land management prac-

\begin{tabular}{|c|c|c|c|c|c|}
\hline Land management practice & $\begin{array}{l}\text { Mean } \\
\text { carbon } \\
\text { uestration } \\
\mathrm{C} \mathrm{ha}^{-1} \mathrm{yr}^{-1}\end{array}$ & $\begin{array}{l}\text { Mitigation potential } \\
\qquad \mathrm{tCO}_{2} \mathrm{eha}^{-1} \mathrm{yr}^{-1}\end{array}$ & $\begin{array}{l}\text { Land emissions }{ }^{\circ} \\
\mathrm{N}_{2} \mathrm{O} \text { and } \mathrm{CH}_{4} \mathrm{t} \mathrm{yr}^{-1} \\
\qquad \mathrm{CO}_{2} \mathrm{e} \mathrm{ha}^{-1}\end{array}$ & $\begin{array}{c}\text { Process emissions }^{\circ} \\
\text { t } \mathrm{CO}_{2} \mathrm{e} \\
\mathrm{ha}^{-1} \mathrm{yr}^{-1}\end{array}$ & 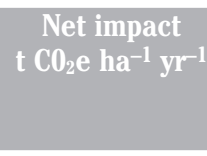 \\
\hline Chemical fertilizer & 264 & 0.97 & -0.33 & -0.35 & 0.29 \\
\hline Animal manure & 325 & 1.19 & 0.05 & 0.94 & 2.18 \\
\hline Mulches & 377 & 1.38 & 0.00 & 0.00 & 1.38 \\
\hline Cover crops & 908 & 3.33 & 0.25 & 0.00 & 3.58 \\
\hline Trees/forest & 1204 & 4.42 & 0.76 & 1.51 & 6.69 \\
\hline Intercropping & 629 & 2.31 & 0.76 & 1.51 & 4.58 \\
\hline Tree-crop farming & 1359 & 4.99 & 0.76 & 1.78 & 7.53 \\
\hline Afforestation & 1163 & 4.27 & 1.41 & 1.87 & 7.55 \\
\hline Grazing pasture & 799 & 2.93 & 0.28 & 0.00 & 3.21 \\
\hline Water harvesting & 839 & 3.08 & 0.66 & 0.23 & 3.97 \\
\hline Slope/barriers & 1193 & 4.38 & 0.66 & 0.23 & 5.27 \\
\hline Terracing & 421 & 1.55 & 0.66 & 0.23 & 2.44 \\
\hline Biochar & 2303 & 8.45 & 1.14 & 0.78 & 10.37 \\
\hline Soil amendment & 569 & 2.09 & 0.05 & 0.94 & 3.08 \\
\hline
\end{tabular}

Table 1. Climate change mitigation benefits of land management practices. 
tice covered in this study was translated into climate change mitigation benefits. The carbon sequestered was calculated in terms of $\mathrm{tCO}_{2}$ eha-1 $\mathrm{yr}^{-1}$. Table 1 shows the different values for each land management practice based on the mean amount of carbon sequestered. Biochar, afforestation, and tree crop farming have the highest climate change mitigation potential with $10.37,7.55$ and $7.53 \mathrm{tCO}_{2} \mathrm{eha}^{-1} \mathrm{yr}^{-1}$, respectively. Although biochar had the greatest mitigation potential, the use and adoption of this practice may be hindered by the source from which the biomass would be generated. These practices will, among other considerations for other factors, be interpreted with caution in terms of their effectiveness in climate change mitigation. Major issues arising from these findings are that sequestration of carbon in the soil through changes in agricultural land management practices may be more difficult than studies have shown. Also, the ability of a land management practice to achieve additional soil carbon does not automatically imply a net decrease in greenhouse gas emissions. Land emissions are the differences among conventional and improved practices for nitrous oxides and methane expressed in $\mathrm{CO}_{2}$ equivalents. Net impact is the sum of the three columns. Process emissions are those arising from fuel and energy use.

Fertilizers may make no net contribution to mitigation of climate change if $\mathrm{CO}_{2}$ emitted to produce and transport them exceeds the soil storage benefit (Lehmann, 2009; Powlson et al., 2011; Schlesinger, 2010). The net impact of the land management practices for climate change mitigation is relative to the value of carbon sequestered by each of the 14 land management practices (Table 1).

\section{Conclusions}

This review has shown that there is a high potential to sequester additional carbon through selected land management practices. Prominent practices include use of biochar, afforestation, tree crop farming, trees on farmland, cover crops, water harvesting, use of slope and barriers, and use of soil amendments. The performance of these practices depends on soil properties and climatic conditions, and the degree of soil degradation at the time of intervention. The potential of these land management practices for climate change mitigation as found in the review should not be selectively considered but explored in the context of factors that may affect the application of each land management practice and the prevailing conditions. There is a need to integrate these land management practices for carbon sequestration into larger sustainable development and livelihood strategies and practices. This will enhance a holistic approach and reduce some of the constraints that may inhibit the positive effects of land management practices for carbon sequestration.

\section{References}

Eagle A., Henry L., Olander L., Haugen-Kozrya K., Millar N., Robertson G.P., 2010. Greenhouse gas mitigation potential of agricultural land management in the United States: A synthesis of the literature. Technical Working Group on Agricultural Greenhoused Gases (TAGG) Report. Nicholas Institute, Duke University, Durham, USA.

FAO, 2004. Carbon sequestration in dryland soils. World Soil Resources Reports No. 102, Rome, Italy. Available from: ftp:/ftp.fao.org/agV/ agll/docs/wsrr102.pdf

FAO, 2010. Climate Change Implications for Food Security and Natural Resources Management in Africa. Report of the 26th Regional Conference For Africa, Luanda, Angola.

Guo L., Gifford R., 2002. Soil carbon stocks and land use change: a meta analysis. Global Change Biology 8:345-360.

IF0AM, 2009. The Contribution of Organic Agriculture to Climate Change Mitigation. Available from: http://www.ifoam.org/about_ ifoam/around_world/eu_group-new/positions/pdf/IFOAM-CCMitigation-Web.pdf

IL0, 2007. Can low-income countries afford basic social security? Social Security Policy Briefings Paper No. 3, Geneva, Switzerland.

IPCC, 2007. Climate change 2007: Impacts, adaptation and vulnerability: Contribution of Working Group II to the fourth assessment report of the Intergovernmental Panel on Climate Change. Cambridge University Press, UK.

IFPRI, 2009. Climate change: Impact on agriculture and costs of adaptation. Washington DC, USA. Available from: http://www.ifpri. org/sites/default/files/publications/pr21.pdf

Lehmann J., 2009. Biological carbon sequestration must and can be a win-win approach: An editorial comment. Climatic Change 97:459.

NEPAD, 2002. Comprehensive Africa Agriculture Development Programme.

Nellemann C., MacDevette M., Manders T., Eickhout B., Svihus B., Prins A., Kaltenborn B. (eds) 2009. The Environmental Food Crisis. The environment's role in averting future food crises. A UNEP rapid response assessment. Arendal, UNDP.

Powlson D., Whitmore A., Goulding K., 2011. Soil carbon sequestration to mitigate climate change: a critical re-examination to identify the true and the false. European Journal of Soil Science 62:42-55.

Ringler C., Zhu T., Cai X., Koo J., Wang D., 2010. Climate Change Impacts on Food Security in Sub-Saharan Africa: Insights from Comprehensive Climate Change Scenarios. IFPRI Discussion Paper No. 1042, International Food Policy Research Institute, Washington, DC, USA.

Schlesinger W.H., 2010. On fertilizer-induced soil carbon sequestration in China's croplands. Global Change Biology 16:849-850.

Shah M., Fischer G., van Velthuizen H., (2008). Food Security and Sustainable Agriculture. The Challenges of Climate Change in Sub-Saharan Africa. International Institute for Applied Systems Analysis, Laxenburg.

Vagen T-G., Lal R., Singh B.R., 2005. Soil carbon sequestration in subSaharan Africa: A review. Land Degradation \& Development 16:5371

Wiggins S., 2006. Agricultural growth and poverty reduction: A scoping study. Working Paper No. 2 on Globalization, Growth and Poverty. IDRC, Ottawa, Canada.

World Bank, 2008. World development report 2008: Agriculture for development. Washington, DC, USA. Available from: http://siteresources.worldbank.org/INTWDR2008/Resources/WDR 00 book.pdf 